\title{
Incidence and Risk Factors of In-Stent Restenosis for Symptomatic Intracranial Atherosclerotic Stenosis: A Systematic Review and Meta-Analysis
}

\author{
(D) G. Peng, (D) Y. Zhang, and (D) Z. Miao
}

\begin{abstract}
BACKGROUND: In-stent restenosis affects long-term outcome in patients with intracranial atherosclerotic stenosis.

PURPOSE: The aim of this meta-analysis was to evaluate the incidence and risk factors of in-stent restenosis.

DATA SOURCES: All literature that reported in-stent restenosis was searched on PubMed, Ovid EMBASE and Ovid MEDLINE data bases.

STUDY SELECTION: Original articles about stents for symptomatic intracranial atherosclerotic stenosis were selected.

DATA ANALYSIS: Meta-analysis was conducted to derive the pooled in-stent restenosis using a random-effects model. Metaregression was performed to explore the risk factors predisposing to in-stent restenosis.

DATA SYNTHESIS: In total, 51 studies with 5043 patients were included. The pooled incidence rate of in-stent restenosis was 14.8\% (95\% Cl, $11.9 \%-17.9 \%)$. Among the lesions with in-stent restenosis, $28.8 \%$ of them led to $(95 \% \mathrm{Cl}, 22.0 \%-36.0 \%)$ related neurologic symptoms. The series in the United States had a higher in-stent restenosis rate $(27.0 \% ; 95 \% \mathrm{Cl}, 20.6 \%-33.9 \%)$ compared with those from Asia (13.6\%; 95\% Cl, 10.3\%-17.2\%) and other regions as a whole $(7.6 \% ; 95 \% \mathrm{Cl}, 1.1 \%-18.1 \%)(P<.01)$. Multiregression analysis revealed that younger patient age was related to high in-stent restenosis rates $(P=.019)$, and vertebrobasilar junction location $(P=.010)$ and low residual stenosis $(P=.018)$ were 2 independent risk factors for symptomatic in-stent restenosis rate.
\end{abstract}

LIMITATIONS: The heterogeneity of most outcomes was high.

CONCLUSIONS: Our study showed promising results of in-stent restenosis for symptomatic atherosclerotic stenosis. Studies are needed to further expatiate on the mechanisms by which younger patient age, vertebrobasilar junction location, and low residual stenosis could increase in-stent restenosis and symptomatic in-stent restenosis, respectively.

ABBREVIATIONS: ISR $=$ in-stent restenosis; MINORS = Methodological Index for Non-Randomized Studies; PRISMA = Preferred Reporting Items for Systematic Reviews and Meta-Analyses; SAMMPRIS = Stenting vs. Aggressive Medical Management for Preventing Recurrent Stroke in Intracranial Stenosis; SES $=$ self-expandable stent

ntracranial atherosclerotic stenosis leads to a remarkable decrease of cerebral perfusion and is responsible for approximately $8 \%-10 \%$ of all ischemic strokes. ${ }^{1,2}$ According to the results of several randomized clinical trials, including the Warfarin-

Received March 31, 2020; accepted after revision May 22.

From the Interventional Neuroradiology Center (G.P., Y.Z., Z.M.), Beijing Tiantan Hospital, and Beijing Neurosurgical Institute (Y.Z.), Capital Medical University, Beijing, China; and China National Clinical Research Center for Neurological Diseases (Z.M.), Beijing, China.

Please address correspondence to Zhongrong Miao, PhD, Interventional Neuroradiology Center, Beijing Tiantan Hospital, No. 119 South 4th Ring West Road, Fengtai District, Beijing, 100070, China; e-mail: zhongrongm@163.com

Indicates article with supplemental on-line tables.

Indicates article with supplemental on-line photos.

http://dx.doi.org/10.3174/ajnr.A6689
Aspirin Symptomatic Intracranial Disease Study (WASID), Stenting vs. Aggressive Medical Management for Preventing Recurrent Stroke in Intracranial Stenosis (SAMMPRIS), and VISSIT Intracranial Stent Study for Ischemic Therapy (VISSIT), the annual rate of recurrent strokes of patients with intracranial atherosclerotic stenosis could be as high as $12.2 \%-20.4 \%$ despite aggressive medical treatment. ${ }^{3-5}$ Stent placement as a major technique of endovascular treatment can reduce the stroke recurrence in patients who were refractory to aggressive medical treatment. The Wingspan Stent System Post Market Surveillance Study (WEAVE) has shown that the incidence of perioperative complications can be reduced to $2.6 \% .^{6}$ In-stent restenosis (ISR) is another important risk factor for long-term stroke recurrence in the patients with stents. Patients with ISR had an approximately 
$10 \%$ higher risk of an ischemic event, which occurred earlier simultaneously than those without ISR after stent implantation. ${ }^{7,8}$ The incidence of ISR differs among the available studies, varying from $5 \%$ to $30 \%$, and reliable analyses of risk factors of ISR are still lacking until now. ${ }^{8-11}$ In this meta-analysis, we aimed to evaluate the incidence of ISR and identify the relative risk factors.

\section{MATERIALS AND METHODS Literature Search}

We searched the literature (last search August 30, 2019) via the databases PubMed, Ovid EMBASE, and Ovid MEDLINE and following the Preferred Reporting Items for Systematic Reviews and Meta-Analyses (PRISMA) guidelines. ${ }^{12}$ The inclusion criteria were stents for symptomatic intracranial atherosclerotic stenosis. The following key words were used and limited to the title and abstract: ("stent" or "stents" or "angioplasty") and ("stenosis" or "atherosclerosis" or "atherosclerotic" or "occlusion") and ("cerebral" or "intracranial"). The studies included had data of ISR as one of the outcomes. Exclusion criteria were the following: 1) articles written in languages other than English; 2) reviews, comments, protocols, editorials, letters, case reports, or animal trials; 3) studies with multiple treatments like primary balloon angioplasty or with extracranial artery stenosis in which data could not be separated; 4) studies on the treatment of complex cerebral artery stenosis; 5) studies on imaging evaluation or treatment of ISR; and 6) series with sample sizes of $<20$.

\section{Data Extraction and Quality Scoring}

We extracted the following data: 1) patient characteristics, including age, sex, hypertension, diabetes, hyperlipemia, smoking, coronary heart disease, ischemic stroke or TIA as a qualifying event, and duration from symptom to treatment; 2) lesion characteristics, including lesion location (internal carotid artery, middle cerebral artery, anterior cerebral artery, vertebral artery, basilar artery, vertebrobasilar artery, and posterior cerebral artery), degree of preprocedural stenosis, length and Mori type of lesion; 3) procedure-related characteristics, including stent type, procedural success, degree of residual stenosis, and periprocedural complications; and 4) image follow-up characteristics, including image follow-up rate, mean image follow-up time, ISR rate, and symptomatic ISR rate. ISR was defined as an angiographically verified $>50 \%$ stenosis within or at the edge of the stent. All the included cohort studies were assessed by the Newcastle-Ottawa Scale and single-arm studies assessed by the Methodological Index for Non-Randomized Studies (MINORS) (On-line Tables 1 and 2). ${ }^{13,14}$ Studies with a Newcastle Ottawa Scale score of $>5$ and a MINORS score of $>10$ were considered high-quality studies.

\section{Statistical Analysis}

Statistical heterogeneity of the data was measured by the Higgins index $\left(\mathrm{I}^{2}\right)$, and the DerSimonian and Laird random-effects model was used. $\mathrm{I}^{2}<60 \%$ was considered as little-to-moderate heterogeneity, while $\mathrm{I}^{2}>60 \%$ was considered substantial heterogeneity. The pooled ISR was represented on a forest plot with 95\% CI. The publication bias was assessed by the Egger test and was illustrated on a funnel plot (On-line Figs 1 and 2). All $P$ values were
2 -sided, and a statistically significant difference was $P<.05$. All analyses were performed with the "meta" and "metafor" packages in R statistical and computing software, Version 3.4.3 (http:// www.r-project.org/).

\section{RESULTS}

\section{Description of Studies}

There were 646 studies found in the first search. After screening the article and assessing the full text, a total of 51 studies met the inclusion and exclusion criteria, and 5043 patients with 5168 lesions were included in our analysis. ${ }^{4,711,15-59}$ Among these, 4 studies were prospective multicentric, 7 were single-center prospective, 8 were retrospective multicentric, and 32 were retrospective single-center series. The PRISMA flow diagram of our analysis is shown in On-line Fig 3.

\section{Patient Population and Characteristics}

The mean age of patients was 60.1 years (range, $48.1-70.5$ years), and the proportion of male patients was $73.6 \%(3712 / 5043 ; 95 \%$ CI, $\left.71.1 \%-76.1 \% ; I^{2}=71 \%\right)$. The most common risk factors were hypertension $\left(3772 / 5043=74.8 \%\right.$; $95 \%$ CI, $70.9 \%-78.7 \%$; $\mathrm{I}^{2}=$ $87 \%)$, hyperlipidemia $(2416 / 5043=47.9 \%$; $95 \%$ CI, $42.1 \%-$ $\left.54.6 \% ; \mathrm{I}^{2}=95 \%\right)$, smoking $(2073 / 5043=41.1 \% ; 95 \% \mathrm{CI}$, $34.9 \%-47.3 \%$; $\left.\mathrm{I}^{2}=93 \%\right)$, diabetes $(1725 / 5043=34.2 \%$; $95 \% \mathrm{CI}$, $\left.30.0 \%-38.4 \% ; \mathrm{I}^{2}=88 \%\right)$, and coronary artery disease (908/ $5043=18.0 \%$; $95 \%$ CI, $15.0 \%-20.9 \%$; $\left.\mathrm{I}^{2}=69 \%\right)$. As the qualifying agent, $57.2 \%$ of patients $(2885 / 5043$; $95 \%$ CI, 50.8\%-63.6\%; $\left.\mathrm{I}^{2}=94 \%\right)$ had ischemic stroke, while $41.2 \%$ patients $(2078 / 5043$; $95 \% \mathrm{CI}, 34.2 \%-48.3 ; \mathrm{I}^{2}=94 \%$ ) had transient ischemic attack as the qualifying event.

On the whole, $57.1 \%$ of lesions (95\% CI, $44.9 \%-68.8 \%$; $\mathrm{I}^{2}=$ 98.5\%) had anterior circulation artery stenosis, while $43.8 \%$ (95\% CI, $31.9 \%-56.0 \%$; $\mathrm{I}^{2}=98.5 \%$ ) were posterior circulation lesions. According to Mori type, Mori A was 24.1\% (95\% CI, 17.6\%-31.1\%; $\mathrm{I}^{2}=86.6 \%$ ), Mori B was 55.1\% (95\% CI, 48.1\%-62.0\%; $\mathrm{I}^{2}=74.7 \%$ ), and Mori C was 21.5\% (95\% CI, $14.7 \%-29.2 \%$; $\mathrm{I}^{2}=84.1 \%$ ). Among these patients, balloon-mounted stents were used in $31.7 \%$ (95\% CI, $16.3 \%-49.3 \% ; \mathrm{I}^{2}=99.3 \%$ ) of patients, and self-expandable stents were used in $68.3 \%$ (95\% CI, 50.7\%-83.7\%; $\mathrm{I}^{2}=99.3 \%$ ).

\section{ISR and Its Risk Factors}

A total of 3652 lesions (70.7\%) had imaging follow-up. The mean image follow-up time was 17.8 months (range, 5.9-180.0 months). For lesions with at least 1 imaging follow-up, the rate of ISR amounted to $14.8 \%$ (95\% CI, $11.9 \%-17.9 \%$; $\mathrm{I}^{2}=82 \%$ ) (On-line Fig 4).

The ISR rate was lower in older patients $(P=.009)$ (On-line Fig 5). Prospective studies had higher ISR rates than retrospective studies (20.9\%; 95\% CI, $16.0 \%-26.3 \%$; $\mathrm{I}^{2}=69 \%$ versus $13.2 \%$; $95 \%$ CI, $10.0 \%-16.7 \%$; $\mathrm{I}^{2}=82 \% ; P=.02$ ) (On-line Fig 6). Series in United States had higher ISR rates (27.0\%; 95\% CI, 20.6\%$33.9 \%$; $\mathrm{I}^{2}=30 \%$ ) compared with those from Asia (13.6\%; $95 \%$ CI, $\left.10.3 \%-17.2 \% ; \mathrm{I}^{2}=83 \%\right)$ and other regions as a whole $(7.6 \%$; 95\% CI, $1.1 \%-18.1 \% ; \mathrm{I}^{2}=80 \% ; P<.01$ ) (On-line Fig 7). Meanwhile, the ISR rate was significantly higher in studies with imaging follow-up rates below $60 \%$ than in the studies with image follow-up rates above $60 \%\left(21.6 \%\right.$; $95 \%$ CI, $16.1 \%-27.6 \%$; $\mathrm{I}^{2}=$ 
Analysis of meta-regression with in-stent restenosis according to patient population and characteristics

\begin{tabular}{|c|c|c|c|}
\hline & No. of Studies & $P$ Value & Heterogeneity $I^{2}(\%)$ \\
\hline \multicolumn{4}{|l|}{ Patient characteristics } \\
\hline Mean age & 46 & .009 & 78.4 \\
\hline Male \% & 47 & .752 & 82.8 \\
\hline Hypertension & 34 & .710 & 84.2 \\
\hline Diabetes & 34 & .267 & 83.5 \\
\hline Hyperlipemia & 32 & .054 & 78.1 \\
\hline Smoking & 34 & .946 & 83.7 \\
\hline IS as the qualifying event & 36 & .513 & 84.2 \\
\hline TIA as the qualifying event & 33 & .621 & 81.0 \\
\hline $\begin{array}{l}\text { Duration from symptom to treatment } \\
\text { Lesion characteristics }\end{array}$ & 20 & .489 & 82.3 \\
\hline Anterior circulation & 47 & .995 & 82.2 \\
\hline ICA & 44 & .956 & 81.4 \\
\hline MCA & 44 & .924 & 81.4 \\
\hline ACA & 44 & .161 & 80.4 \\
\hline Posterior circulation & 47 & .998 & 82.2 \\
\hline VA & 42 & .122 & 80.8 \\
\hline BA & 42 & .208 & 80.4 \\
\hline VBJ & 42 & .232 & 81.0 \\
\hline PCA & 43 & .951 & 81.1 \\
\hline Preprocedural stenosis degree & 42 & .368 & 81.4 \\
\hline Length of stenosis & 17 & .731 & 79.0 \\
\hline \multicolumn{4}{|l|}{ Mori type } \\
\hline Mori A & 13 & .955 & 72.1 \\
\hline Mori B & 12 & .705 & 52.3 \\
\hline Mori C & 12 & .987 & 53.3 \\
\hline \multicolumn{4}{|l|}{ Procedure-related characteristics } \\
\hline Procedural success rate & 42 & .052 & 80.1 \\
\hline Stent type (BMS or SES) & 47 & .817 & 83.6 \\
\hline Mean degree of residual stenosis & 38 & .778 & 80.9 \\
\hline Periprocedural complication rate & 43 & .699 & 82.5 \\
\hline \multicolumn{4}{|l|}{ Image follow-up characteristics } \\
\hline Image follow-up time (mo) & 46 & .404 & 83.1 \\
\hline Image follow-up rate $>60 \%$ & 51 & .004 & 81.2 \\
\hline
\end{tabular}

Note:-IS indicates ischemic stroke; ACA, anterior cerebral artery; VA, vertebral artery; BA, basilar artery; VBJ, vertebrobasilar junction; PCA, posterior cerebral artery; BMS, balloon-mounted stent.

$73 \%$ versus $12.2 \%$; 95\% CI, 9.1\%-15.7\%; $\mathrm{I}^{2}=83 \%$; $\left.P<.01\right)(\mathrm{On}-$ line Fig 8). Overall, the ISR rate was not statistically related to hypertension, diabetes, lesion location, length of stenosis, procedural success rate, degree of residual stenosis, and other variables (Table). Results of multiregression analysis showed that younger age was the only independent risk factor that predicted high ISR rates $(P=.019)$.

\section{Risk Factors for Symptomatic ISR}

Among the lesions with ISR at follow-up, 28.8\% (95\% CI, 22.0\%$36.0 \% ; \mathrm{I}^{2}=44 \%$ ) were symptomatic. Meanwhile, the symptomatic ISR rate was $4.3 \%\left(95 \% \mathrm{CI}, 3.0 \%-5.7 \%\right.$; $\left.\mathrm{I}^{2}=53 \%\right)$ in the total study population.

First, symptomatic ISR was correlated to the sample size of the series. Symptomatic ISR increased as the sample enlarged $(P=.001)$ (On-line Fig 9). Second, according to the results of subgroup analysis, the studies in the United States had higher symptomatic ISR rates (8.7\%; 95\% CI, 5.0\%-13.2\%; $\mathrm{I}^{2}=0 \%$ ) than those in Asia (4.3\%; 95\% CI, 3.1\%-5.6\%; $\left.\mathrm{I}^{2}=30 \%\right)$ and other regions $\left(0.0 \%\right.$; $95 \% \mathrm{CI}, 0.0 \%-2.3 \%$; $\left.\mathrm{I}^{2}=0 \%\right)(P<.01)$. Third, older individuals also had lower symptomatic ISR rates $(P=.046)$ (On-line Fig 10). Fourth, the symptomatic ISR rate was also lower in studies with an imaging follow-up rate of $>60 \%$ than in the studies with an image follow-up rate of $<60 \%(3.4 \%$; $95 \% \mathrm{CI}, 2.1 \%$ $5.1 \% ; \mathrm{I}^{2}=58 \%$ versus $6 \% ; 95 \% \mathrm{CI}$, $\left.4 \%-9 \% ; \mathrm{I}^{2}=28 \%, P=.02\right)$. In multivariate regression analysis, vertebrobasilar junction location $(P=.010)$ and low residual stenosis $(P=.018)$ were independent risk factors for the symptomatic ISR rate (On-line Figs 11 and 12).

\section{Heterogeneity}

Moderate heterogeneity between effect estimates was observed for Mori B and Mori C lesions. Substantial heterogeneity between effect estimates was observed in the following variables: age, male sex, hypertension, diabetes, hyperlipemia, smoking, ischemic stroke or TIA as the qualifying event, duration from symptom to treatment, lesion location, peristenosis, length of stenosis, Mori A lesion, procedural success rate, stent type, and image follow-up rate (Table).

\section{DISCUSSION}

Our meta-analysis showed that $14.8 \%$ of symptomatic patients with intracranial atherosclerotic stenosis after stent implantations may experience ISR. Among these patients with ISR, 28.8\% would have symptoms. The symptomatic ISR rate was $4.3 \%$ in the whole patient population, which was much lower than that in the SAMMPRIS trial. ${ }^{60}$

The SAMMPRIS trial is a prospective randomized controlled trial whose subgroup analysis of symptomatic ISR included 183 patients, and the image follow-up rate was $<60 \%$. The result of our meta-analysis showed that prospective studies had higher ISR rates than retrospective studies due to younger age (58.8 \pm 5.2 versus $60.4 \pm 4.8$ years, $P=.37$ ) in prospective studies, which was the risk factor for ISR. The symptomatic ISR rate was higher in the studies with relatively low image follow-up rates as well. Meanwhile, the subgroup analysis of SAMMPRIS of symptomatic ISR enrolled 4 patients with primary balloon angioplasty; therefore, this meta-analysis excluded it.

In our study, we found that the reported ISR rate decreased as the image follow-up rate increased because the low image followup rate reflected the overall patient compliance with physicians' suggestions. The patients would not consider an invasive DSA follow-up until there were new-onset postprocedural symptoms. Therefore, in the series with a lower image follow-up rate, most of the patients came back only when they were symptomatic due to ISR. On the contrary, a higher image follow-up rate can reduce follow-up bias, and the ISR rate would be much closer to the real 
situation. Our study showed that when the rate of image followup was higher than $60 \%$, the incidence of ISR and symptomatic ISR was significantly lower. The total image follow-up rate of this meta-analysis was 77.3\%; among these studies, 35 studies (68.6\%) had image follow-up rates above $60 \%$, with ISR rates of $12.2 \%$ and symptomatic ISR rates of $3.4 \%$. This finding might have certain guiding significance for further study designs.

Lesion location as one of risk factors of ISR has been described previously. In the series of Turk et al, ${ }^{58}$ the supraclinoid segment of the ICA tended to have higher ISR. In our study, the incidence of ISR and symptomatic ISR showed no notable difference between the anterior and posterior circulation, but a higher rate of symptomatic ISR was noticed in the lesions at the vertebrobasilar junction. Parent vessel tortuosity is more commonly seen in this location, thus hampering the apposition of the stent to the vessel wall and predisposing this location to higher risk of ISR.

Moreover, we also identified a disparity of reported ISR rates among different regions. Higher incidences of ISR and symptomatic ISR were observed in patients in the United States compared with patients in Asia and other areas like Germany, Italy, Turkey, and Argentina. There was no significant difference in procedural success rates and residual stenosis rates among different regions. The mean image follow-up rate of studies in the United States was $65.2 \%$, lower than that of studies in other regions $(79.7 \%)(P=.08)$. The studies in the United States also had lower residual stenosis rates $(14.8 \% \pm 5.2 \%$ versus $16.7 \% \pm$ $8.2 \%, P=.654)$ and a higher proportion of vertebrobasilar junction locations $(2.8 \% \pm 4.3 \%$ versus $2.0 \% \pm 7.7 \%, P=.038)$ than in other regions. Although without a statistical difference, these might have caused higher rates of ISR and symptomatic ISR in the studies in the United States.

Several studies have demonstrated that larger residual stenosis may be a predictor of restenosis after stent placement, especially when residual stenosis is $>30 \%{ }^{45,51,52}$ This finding is in accordance with our instincts, because larger residual stenosis might reflect lesions not being adequately treated. What if the lesions are adequately treated? Should we more aggressively minimize the residual stenosis to the best result possible? In our analysis, most of the included studies $(36 / 38,94.7 \%)$ had a residual stenosis of under $30 \%$, indicating that most of the lesions were properly handled. However, the multivariate regression analysis suggested that lower residual stenosis was related to higher symptomatic ISR rates. This result is surprising, but it might hint that treating the lesions more aggressively added no more benefit. When residual stenosis is $<30 \%$, lower residual stenosis may indicate more vascular endothelial damage during the procedure; that could lead to a higher risk of symptomatic ISR.

We also identified another counterintuitive factor, namely younger age, that led to higher ISR rates post-stent implantation. Turk et $\mathrm{al}^{58}$ also reported that ISR is more common in younger patients after treatment with the Wingspan system. One reason the authors hypothesized was that lesions in younger patients represented more of inflammatory arteriopathy than primary atherosclerosis. Previous research has shown that inflammatory connective tissue disease is associated with cardiovascular risk and there was a negative interaction between connective tissue disease and age. ${ }^{61}$ We suspect that the inflammatory response may be more active in younger patients with atherosclerotic disease facing a greater risk of ISR, but more proof and evidence are needed.

Our study showed no association between the ISR rate and different stent types, including balloon-mounted stents and self-expandable stents (SESs). Previous studies and a systematic review suggested that lesions with SESs were more prone to ISR than those with balloon-mounted stents due to the higher residual stenosis degree, higher flexibility, and the lower radial force of SESs. ${ }^{36,62,63}$ Our study presented higher degrees of residual stenosis after SES implantation as well $(P=.033)$. The negative correlation between residual stenosis and the ISR rate found in this study may conceal positive correlations of SES. Further studies are needed to identify whether the lesions with SES have higher restenosis rates and the physiopathologic mechanism.

Several limitations of our meta-analysis need to be discussed. First, most studies were retrospective, and the sample size in $72 \%$ of series was $<100$ patients. The target population of studies varied within the inclusion criteria, resulting in limited generalization of population characteristics such as distribution of lesion location, proportion of stent types used, and preprocedural stenosis degree. Second, the variables extracted from studies were limited because of the meta-analysis design. Age and residual stenosis are important risk factors for ISR. However, we could only analyze the relationship between mean age and mean residual stenosis of each study and ISR. The platelet inhibition ratio, indicators of inflammatory response, serum lipid levels, and blood glucose levels during the follow-up period that may lead to ISR were rarely mentioned in the studies. Third, the patients' enrollment in these studies spanned 2 decades (1996-2018), during which time the technique of intracranial stent implantation and the standardization and compliance of medications have improved. These factors may also have an effect on ISR. In addition, there was considerable heterogeneity in the effect estimates of some risk factors we studied.

Our study has some implications for clinical practice. The risk factors discussed in the meta-analysis could help neurointerventionists develop more cautious operation and image follow-up plans when patients have a high risk for ISR.

\section{CONCLUSIONS}

Our study showed promising results of in-stent restenosis for symptomatic atherosclerotic stenosis. Studies are needed to further expatiate on the mechanisms by which younger patient age, vertebrobasilar junction location, and low residual stenosis could increase ISR and symptomatic ISR, respectively.

\section{REFERENCES}

1. Sacco RL, Kargman DE, Gu Q, et al. Race-ethnicity and determinants of intracranial atherosclerotic cerebral infarction: the Northern Manhattan Stroke Study. Stroke 1995;26:14-20 CrossRef Medline

2. Wityk RJ, Lehman D, Klag M, et al. Race and sex differences in the distribution of cerebral atherosclerosis. Stroke 1996;27:1974-80 CrossRef Medline 
3. Chimowitz MI, Lynn MJ, Derdeyn CP, et al; SAMMPRIS Trial Investigators. Stenting versus aggressive medical therapy for intracranial arterial stenosis. N Engl J Med 2011;365:993-1003 CrossRef Medline

4. Zaidat OO, Fitzsimmons BF, Woodward BK, et al; VISSIT Trial Investigators. Effect of a balloon-expandable intracranial stent vs medical therapy on risk of stroke in patients with symptomatic intracranial stenosis: the VISSIT randomized clinical trial. JAMA 2015;313:1240-48 CrossRef Medline

5. Chimowitz MI, Lynn MJ, Howlett-Smith H, et al; Warfarin-Aspirin Symptomatic Intracranial Disease Trial Investigators. Comparison of warfarin and aspirin for symptomatic intracranial arterial stenosis. N Engl J Med 2005;352:1305-16 CrossRef Medline

6. Alexander MJ, Zauner A, Chaloupka JC, et al; WEAVE Trial Sites and Interventionalists. WEAVE trial: final results in 152 on-label patients. Stroke 2019;50:889-94 CrossRef Medline

7. Jin $\mathrm{M}, \mathrm{Fu} \mathrm{X}$, Wei $\mathrm{Y}$, et al. Higher risk of recurrent ischemic events in patients with intracranial in-stent restenosis. Stroke 2013;44:2990-94 CrossRef Medline

8. Levy EI, Turk AS, Albuquerque FC, et al. Wingspan in-stent restenosis and thrombosis: incidence, clinical presentation, and management. Neurosurgery 2007;61:644-50; discussion 50-51 CrossRef Medline

9. Alurkar A, Karanam LS, Oak S, et al. Role of balloon-expandable stents in intracranial atherosclerotic disease in a series of $\mathbf{1 8 2}$ patients. Stroke 2013;44:2000-03 CrossRef Medline

10. Li J, Zhao ZW, Gao GD, et al. Wingspan stent for high-grade symptomatic vertebrobasilar artery atherosclerotic stenosis. Cardiovasc Intervent Radiol 2012;35:268-78 CrossRef Medline

11. Zhang L, Huang Q, Zhang Y, et al. Wingspan stents for the treatment of symptomatic atherosclerotic stenosis in small intracranial vessels: safety and efficacy evaluation. AJNR Am J Neuroradiol 2012;33:343-47 CrossRef Medline

12. Moher D, Liberati A, Tetzlaff J, et al; PRISMA Group. Preferred reporting items for systematic reviews and meta-analyses: the PRISMA statement. J Clin Epidemiol 2009;62:1006-12 CrossRef Medline

13. Slim K, Nini E, Forestier D, et al. Methodological Index for NonRandomized Studies (MINORS): development and validation of a new instrument. ANZ J Surg 2003;73:712-76 CrossRef Medline

14. Wells GA, Shea B, O'Connell D, et al. The Newcastle-Ottawa Scale (NOS) for assessing the quality of nonradomized studies in metaanalyses. 2014. Ottawal Hospital Research Institute. https://www. researchgate.net/publication/288802810_The_Newcastle-Ottawa_Scale_ NOS_for_Assessing_The_Quality_of_Nonrandomised_Studies_in_ Meta-analyses. Assessed November 19, 2019

15. Bai WX, Gao BL, Li TX, et al. Wingspan stenting can effectively prevent long-term strokes for patients with severe symptomatic atherosclerotic basilar stenosis. Interv Neuroradiol 2016;22:318-24 CrossRef Medline

16. Bose A, Hartmann M, Henkes $\mathrm{H}$, et al. A novel, self-expanding, nitinol stent in medically refractory intracranial atherosclerotic stenoses: the Wingspan study. Stroke 2007;38:1531-57 CrossRef Medline

17. Du Z, Mang J, Yu S, et al. Weighing in on the off-label use: initial experience of Neuroform EZ stenting for intracranial arterial stenosis in 45 patients. Front Neurol 2018;9:852 CrossRef Medline

18. Durst CR, Geraghty SR, Southerland AM, et al. Stenting of symptomatic intracranial stenosis using balloon mounted coronary stents: a single center experience. J Neurointerv Surg 2015;7:245-49 CrossRef Medline

19. Feng Z, Duan G, Zhang P, et al. Enterprise stent for the treatment of symptomatic intracranial atherosclerotic stenosis: an initial experience of 44 patients. BMC Neurol 2015;15:187 CrossRef Medline

20. Fiorella D, Chow MM, Anderson M, et al. A 7-year experience with balloon-mounted coronary stents for the treatment of symptomatic vertebrobasilar intracranial atheromatous disease. Neurosurgery 2007;61:236-42; discussion 42-43 CrossRef Medline

21. Freitas JM, Zenteno M, Aburto-Murrieta $Y$, et al. Intracranial arterial stenting for symptomatic stenoses: a Latin American experience. Surg Neurol 2007;68:378-86 CrossRef Medline
22. Gandini R, Chiaravalloti A, Pampana E, et al. Intracranial atheromatous disease treatment with the Wingspan stent system: evaluation of clinical, procedural outcome and restenosis rate in a single-center series of 21 consecutive patients with acute and mid-term results. Clin Neurol Neurosurg 2013;115:741-47 CrossRef Medline

23. Guo XB, Ma N, Hu XB, et al. Wingspan stent for symptomatic M1 stenosis of middle cerebral artery. Eur J Radiol 2011;80:e356-60 CrossRef Medline

24. He Y, Wang Z, Li T, et al. Preliminary findings of recanalization and stenting for symptomatic vertebrobasilar artery occlusion lasting more than $24 \mathrm{~h}$ : a retrospective analysis of 21 cases. Eur J Radiol 2013;82:1481-86 CrossRef Medline

25. Jiang WJ, Cheng-Ching E, Abou-Chebl A, et al. Multicenter analysis of stenting in symptomatic intracranial atherosclerosis. Neurosurgery 2012;70:25-30; discussion 31 CrossRef

26. Jiang WJ, Xu XT, Du B, et al. Comparison of elective stenting of severe vs moderate intracranial atherosclerotic stenosis. Neurology 2007;68:420-26 CrossRef Medline

27. Jiang WJ, Yu W, Du B, et al. Outcome of patients with $\geq 70 \%$ symptomatic intracranial stenosis after Wingspan stenting. Stroke 2011;42:197175 CrossRef Medline

28. Kim KS, Hwang DH, Ko YH, et al. Usefulness of stent implantation for treatment of intracranial atherosclerotic stenoses. Neurointervention 2012;7:27-33 CrossRef Medline

29. Lee KY, Chen DY, Hsu HL, et al. Undersized angioplasty and stenting of symptomatic intracranial tight stenosis with Enterprise: evaluation of clinical and vascular outcome. Interv Neuroradiol 2016;22:187-95 CrossRef Medline

30. Li G, Wang N, Li X, et al. Balloon-mounted versus self-expanding stent outcomes in symptomatic middle cerebral artery stenosis combined with poor collaterals in China: a multicenter registry study. World Neurosurg 2019 Jan 16 [Epub ahead of Print] CrossRef Medline

31. Li TX, Gao BL, Cai DY, et al. Wingspan stenting for severe symptomatic intracranial atherosclerotic stenosis in $\mathbf{4 3 3}$ patients treated at a single medical center. PLoS One 2015;10:e139377 CrossRef Medline

32. Li Y, Tang L, Qi D, et al. Correlation between high perfusion syndrome and stent restenosis after stent implantation. Exp Ther Med 2016;12:3675-79 CrossRef Medline

33. Lylyk P, Vila JF, Miranda C, et al. Endovascular reconstruction by means of stent placement in symptomatic intracranial atherosclerotic stenosis. Neurol Res 2005;27(Suppl 1):S84-88 CrossRef Medline

34. Maier IL, Karch A, Lipke C, et al. Transluminal angioplasty and stenting versus conservative treatment in patients with symptomatic basilar artery stenosis: perspective for future clinical trials. Clin Neuroradiol 2018;28:33-38 CrossRef Medline

35. Miao ZR, Feng L, Li S, et al. Treatment of symptomatic middle cerebral artery stenosis with balloon-mounted stents: long-term followup at a single center. Neurosurgery 2009;64:79-84 CrossRef Medline

36. Park S, Kim JH, Kwak JK, et al. Intracranial stenting for severe symptomatic stenosis: self-expandable versus balloon-expandable stents. Interv Neuroradiol 2013;19:276-82 CrossRef Medline

37. Park SC, Cho SH, Kim MK, et al. Long-term outcome of angioplasty using a Wingspan stent, post-stent balloon dilation and aggressive restenosis management for intracranial arterial stenosis. Clin Neuroradiol 2020;30:159-69 CrossRef Medline

38. Qureshi AI, Hussein HM, El-Gengaihy A, et al. Concurrent comparison of outcomes of primary angioplasty and of stent placement in highrisk patients with symptomatic intracranial stenosis. Neurosurgery 2008;62:1053-60; discussion 60-62 CrossRef Medline

39. Salik AE, Selcuk HH, Zalov H, et al. Medium-term results of undersized angioplasty and stenting for symptomatic high-grade intracranial atherosclerotic stenosis with Enterprise. Interv Neuroradiol 2019;25:484-90 CrossRef Medline

40. Samaniego EA, Tari-Capone F, Linfante I, et al. Wingspan experience in the treatment of symptomatic intracranial atherosclerotic 
disease after antithrombotic failure. J Neurointerv Surg 2013;5:30205 CrossRef Medline

41. Shin YS, Kim BM, Suh SH, et al. Wingspan stenting for intracranial atherosclerotic stenosis: clinical outcomes and risk factors for in-stent restenosis. Neurosurgery 2013;72:596-604; discussion 604 CrossRef Medline

42. Suh DC, Kim JK, Choi JW, et al. Intracranial stenting of severe symptomatic intracranial stenosis: results of 100 consecutive patients. AJNR Am J Neuroradiol 2008;29:781-85 CrossRef

43. Tang CW, Chang FC, Chern CM, et al. Stenting versus medical treatment for severe symptomatic intracranial stenosis. AJNR Am J Neuroradiol 2011;32:911-16 CrossRef Medline

44. Wang X, Wang Z, Wang C, et al. Application of the Enterprise stent in atherosclerotic intracranial arterial stenosis: a series of $\mathbf{6 0}$ cases. Turk Neurosurg 2016;26:69-76 CrossRef Medline

45. Wang ZL, Gao BL, Li TX, et al. Symptomatic intracranial vertebral artery atherosclerotic stenosis $(\mathbf{2 7 0} \%)$ with concurrent contralateral vertebral atherosclerotic diseases in 88 patients treated with the intracranial stenting. Eur J Radiol 2015;84:1801-04 CrossRef

46. Wang ZL, Gao BL, Li TX, et al. Outcomes of middle cerebral artery angioplasty and stenting with Wingspan at a high-volume center. Neuroradiology 2016;58:161-69 CrossRef

47. Wolfe TJ, Fitzsimmons BF, Hussain SI, et al. Long term clinical and angiographic outcomes with the Wingspan stent for treatment of symptomatic $50-99 \%$ intracranial atherosclerosis: single center experience in 51 cases. J Neurointerv Surg 2009;1:40-43 CrossRef Medline

48. Yu J, Wang L, Deng JP, et al. Treatment of symptomatic intracranial atherosclerotic stenosis with a normal-sized Gateway TM balloon and Wingspan TM stent. J Int Med Res 2010;38:1968-74 CrossRef Medline

49. Yu SC, Leung TW, Lee KT, et al. Angioplasty and stenting of atherosclerotic middle cerebral arteries with Wingspan: evaluation of clinical outcome, restenosis, and procedure outcome. AJNR Am J Neuroradiol 2011;32:753-58 CrossRef Medline

50. Yu SC, Leung TW, Lee KT, et al. Angioplasty and stenting of intracranial atherosclerosis with the Wingspan system: 1-year clinical and radiological outcome in a single Asian center. J Neurointerv Surg 2014;6:96-102 CrossRef Medline

51. Yue X, Xi G, Lu T, et al. Influence of residual stenosis on clinical outcome and restenosis after middle cerebral artery stenting. Cardiovasc Intervent Radiology 2011;34:744-50 CrossRef Medline
52. Zhang L, Huang Q, Zhang Y, et al. A single-center study of Wingspan stents for symptomatic atherosclerotic stenosis of the middle cerebral artery. J Clin Neurosci 2013;20:362-66 CrossRef Medline

53. Zhang Y, Rajah GB, Liu P, et al. Balloon-mounted versus self-expanding stents for symptomatic intracranial vertebrobasilar artery stenosis combined with poor collaterals. Neurol Res 2019;41:704-13 CrossRef Medline

54. Zhang Y, Sun Y, Li X, et al. Early versus delayed stenting for intracranial atherosclerotic artery stenosis with ischemic stroke. $J$ Neurointerv Surg 2020;12:274-78 CrossRef Medline

55. Zhou Y, Hua Y, Jia L, et al. Evaluation of interventional therapy for patients with intracranial vertebral artery stenosis by transcranial color-coded sonography. Ultrasound Med Biol 2016;42:44-50 CrossRef Medline

56. Zhu SG, Zhang RL, Liu WH, et al. Predictive factors for in-stent restenosis after balloon-mounted stent placement for symptomatic intracranial atherosclerosis. Eur J Vasc Endovasc Surg 2010;40:499_ 506 CrossRef Medline

57. Zi W, Gong Z, Shuai J. Novel approaches in evaluating and predicting the potential benefit of middle cerebral artery angioplasty and stenting. J Neuroimaging 2015;25:620-25 CrossRef

58. Turk AS, Levy EI, Albuquerque FC, et al. Influence of patient age and stenosis location on Wingspan in-stent restenosis. AJNR Am J Neuroradiol 2008;29:23-27 CrossRef Medline

59. Duan G, Feng Z, Zhang L, et al. Solitaire stents for the treatment of complex symptomatic intracranial stenosis after antithrombotic failure: safety and efficacy evaluation. J Neurointerv Surg 2016;8:68084 CrossRef Medline

60. Derdeyn CP, Fiorella D, Lynn MJ, et al; SAMMPRIS Investigators. Nonprocedural symptomatic infarction and in-stent restenosis after intracranial angioplasty and stenting in the SAMMPRIS Trial (Stenting and Aggressive Medical Management for the Prevention of Recurrent Stroke in Intracranial Stenosis). Stroke 2017;48:150106 CrossRef Medline

61. Alenghat FJ. The prevalence of atherosclerosis in those with inflammatory connective tissue disease by race, age, and traditional risk factors. Sci Rep 2016;6:20303 CrossRef Medline

62. Yue X, Yin Q, Xi G, et al. Comparison of BMSs with SES for symptomatic intracranial disease of the middle cerebral artery stenosis. Cardiovasc Intervent Radiol 2011;34:54-60 CrossRef Medline

63. Gröschel K, Schnaudigel S, Pilgram SM, et al. A systematic review on outcome after stenting for intracranial atherosclerosis. Stroke 2009;40:e340-47 CrossRef Medline 